\title{
Corporate Governance And Performance Of Peer Firms: A Cross-Lagged Analysis Of An Emerging Economy
}

\author{
Rizwan Ali, Xidian University, China \\ Yanping Liu, Xidian University, China \\ Gul Rukh Niazi, The University of Lahore, Pakistan
}

\begin{abstract}
In this study, we examine the effects of corporate governance practices on financial performance of Pakistani listed firms. On the bases of agency theory, MM theorem, and theory of firm, we suggest that corporate governance effects firm performance directly as well as indirectly via mediation of capital structure and dividend policy. The model was tested using a cross-lagged analysis of 100 non-financial firms with the structural equation modeling (SEM). The study concludes that corporate governance improves financial performance by exploiting capital structure and dividend policy. The findings of this study, highlights the importance of corporate governance practices for peer firms to restructure their debt and dividend policies for the enhancement of their financial performance.
\end{abstract}

Keywords: Corporate Governance; Capital Structure; Dividend Policy; Firm Performance; Cross-Lag Analysis

\section{INTRODUCTION AND LITERATURE REVIEW}

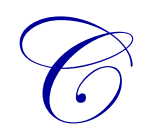

orporate Governance practices is "The set of laws, policies, institutions and process affecting the approach; a company is administered, controlled and directed" (Cadbury, 1992). The term "corporate governance" came into popular use in the 1980's. Corporate governance ensures some key objectives including transparency in both financial and non-financial transactions and accountability of related parties (OECD 1999, revised 2004). (Konzelmann, Wilkinson, Fovargue-Davis and Sankey (2010) explained that corporate governance is dynamic for sustainability of firm and in absence financial instability and depression occurs. Primarily governance concerned with the duties and responsibilities of a company's board of directors to successfully lead the company and the relationship not only with shareholders but also with stakeholder. Corporate governance includes laws, policies to govern "private" and "public" firms. It also establishes business performance measures which collectively govern the relationships among marketplace economy, corporate directors and entrepreneurs, who invest capital in firms.

The purpose of good corporate governance practices makes positive effects on capital structure of firm. Shleifer and Vishny (1997) examined this mechanisms, capital structure decision maker of the firm confirm that they possibly will attain a considerable returns and benefits on their investments. By means of reliable governance structure, it is significantly easier for goodwill of corporations towards not only their shareholder but also their stakeholders. Good corporate governance crate also goodwill of the firm in the market which eventually build the trust of the investors towards their investment of this firm. Governance control not only maintains their good relations to their internal stakeholder but also create good value to their external stockholder. Although governance or top management of the firm maintain a lot of responsibility which mainly includes firms financial performance, firms debt issues either sort term or long term, announcement of dividends etc. Jensen (1993) and Hart and Moore (1995) documented that company managers borrowed debt from the market, financial institutions and other sources but they did not managed it in the favor of companies earrings which against the shareholder interest that's why many companies windup their business even much they were bank corrupt. The lack of accountability and transparency of issuing and re-packaging debt security (see Enron case) in capital structure generates higher cost and lower cash flow only. 
The good corporate governance crate a balance between their capital structure decision and the development of the firm which protect the rights of all stakeholders of firm (Abdullah, Ahmad \& Roslan, 2012). Jensen and Meckling (1976) explain that ownership structure which helps to reduce the agency conflicts, for this reasons it is supporting the interest of shareholders and ownership of the firm. Along with the high significance of conflicts between shareholders and internal managers, the corporate governance mechanisms of the firm are generally considered as an ineffective measure. Fama and Jenson (1983) also argued that the role of chairman and CEO are supposed to be considered as separate from each other, the chairman has the chief decision control authority and CEO has the chief decision executive authority, and the CEO of firm has the responsibility to control all operations of the organization. However, duality is able to increase control as well as taking decision towards improving the entire process of the firms. Wen, Rwegasira \& Bilderbeek (2002) examined the effects of Chinese listed firm's broad structure on the capital structure polices. This study suggests that higher board's corporate governance having impact on lower capital structure, on the other hand size of board member and capital structure revealed insignificant associations. Florackis and Ozkan (2009) also suggest that UK firms have strong evidence about their significance level and explained that the structure of corporate governance also depends, as well defines Sarbanes Oxley Act's causal relationships. Conclusion of the study said that Oxley act has been developed to enhance firm's transparency and governance; it is substitute of capital structure in resolving agency conflict.

Saad (2010) investigated the effect of Malaysian firm's corporate governance compliance on financial leverage. Study concludes the relationship among corporate governance internal mechanisms and capital structure. Magdalena (2012) documented through the panel data of listed firms at Indonesian Stock Exchange, stated that board of director's size inversely effects capital structure procedure while not including bank and financial institutions. Gugler (2003) analyzed the panel data set of Austrian firms and explained the relationship between internal corporate governance mechanisms and dividend payments, gave estimation that corporate governance mechanism determines dividend pay-out ratios. Hu and Kumar (2004) concluded that internal governance mechanisms have significant and relatively positive effects on dividend payments level. Hwang, Park \& Park (2004) examined in the study of Korean business group that good corporate governance pay higher dividends.

Kowalewski, Stetsyuk, \&Talavera (2008) research findings upkeep the argument of dividends payments. The study was particularly focused on Poland market where the firms are bound to pay higher dividends to shareholder because rights are highly protected for shareholders. Adjaoud and Amar (2010) documented that in their study conduct on the data set of Canadian market in which they conclude that effective governance has significant and positivity impact on dividend income for shareholders of the firm. Jiraporn, Kim and Kim (2011) and Abdullah et al. (2012) documented that dividend policy is directly related to the quality of governance which improves overall financial position of the firms except unexpected economic change and also suggest that ownership structure plays an important role to resolve the agency problem. Thanatawee (2013) conducted a study depends on the sample of 1927 observations for a time period of eight years for Thailand listed firms and inferred that ownership structure heavily influences the dividend policy, particularly organizations have to pay higher dividend with the higher percentage of institutional shareholding.

The relationship between corporate governance and firm performance widely discussed in prior literature mainly in developed states and over the last decade It also been discussed in developing and emerging economics based on accounting and market measures of the firm. Mehran (1995) and Klein (1998) documented that firm performance and board committee structure that higher proportion of outside directors on the board has insignificant relationship with firm performance. Gompers, Ishii and Metrick (2003) examined the relationship among governance indicators with long-term equity returns, value of firm and the performance of the firm based on accounting measures. The results revealed that the firms which follow good corporate governance practices shows higher returns on equity, higher value of firm and enhanced accounting results than that firms which have poor corporate governance practices towards controlling and managing the firms activities.

Drobetz, Schillhofer and Zimmermann (2004) illustrated that there is positive relationship between corporate governance practices and expected stock returns employed German publicly listed companies. Javed, Iqbal and Hasan (2006) concluded that corporate governance practices not entirely helpful towards enhancing financial performance of Pakistani listed companies. Some other factors still continue to improve financial performance either these are internal or external factors. Haat, Rahman and Mahenthiran (2008) conducted a comparative study of 73 
good and 73 bad performance listed firms of Malaysian stock exchange based on corporate governance, transparency and performance employed hierarchical regression technique and realized that corporate governance dynamics contain strong predicting influences on the firm performance in Malaysia, in general due to debt monitoring and foreign ownership structure.

Kajola (2008) studied four major corporate governance mechanisms; such as board composition, board size, CEO statue and audit committee. The research findings advocate that the relationship between board composition and two key performance measures return on equity and net profit margin are not statistically proved as significant. On the basis of sampled firms, the implications of the study revealed that no relationship exists between firm performance and corporate governance, when outside directors are the part of overall board size. Ehikioya (2009) and Renders, Gaeremynck and Sercu (2010) examined the positively significant relation between ownership construction and firm performance on the data set of Nigeran Stock Exchange and also found positive relationship between corporate governance mechanisms and firm's performance in a Cross-European study covering fourteen countries. It is further added that the strong points of this relationship appears after some conditions which basically depends upon the excellence and value of institutional environment. Lima and Sanvicente (2013) documented that the main concerns of corporate governance is to determine how a company minimize its costs that increases due to the agency's conflicts and what strategies managers be able to make towards improving the firm's performance. The relationship between capital structure and firm performance on several industries, which noticeable on elevated measure within variation of characteristics beginning wherever development, expenditure and demand (Wippern, 1966). Hurdle (1974) examined that capital structure influence negatively on profitability in concurrence among the two stage least squares (2SLS) and positively according towards ordinary least squares (OLS). Lev (1974) argues that organizations with high leverage have a tendency to illustrate more inconsistency of their accumulation income than comparatively less levered organizations. An enhancement in the leverage increases the risk of the firm's accumulated income.

Jensen and Meckling (1976) examined that the preference of capital structure might facilitate moderate organization costs. They argued that high utilization of debt resources can decrease organization expenditure during the risk of bankruptcy, which causes own losses to managers' salaries, standing, and throughout difficulty to produce cash flow to compensate interests everyday expenditure. Brigham and Gapenski (1996) studded an optimal capital structure is able to survive in that condition if there is a tax sheltering profit make available to enhance in debt intensity is equivalent to the bankruptcy costs. They both also recommend that managers of a firm must be capable to recognize that when the optimal capital structure is achieved they must be struggling to continue it on that point. On that level, the financing expenditures and cost of capital are decreased, in this way firm value and performance are growing. On the other hand, Chhibber and Majumdar (1997) documented that intensity of debt to equity ratio (capital structure) relates inversely among firms financial performance. Abor (2005) reported in their study the combination of capital mainly categorized into short term and long term debt and total debt of the firm. Conclusion suggests that firms those rely on debt particularly, it will not attain tax protections and after that it leads to enhanced debt expenditure of which the firm describes as the economic failure risks and decrease the return. (Bunkanwanicha, Gupta and Rokhim (2008) examined the relationship among debt, decision-making activities and financial performance of the firm in Thai and Indonesian markets. Their results draw attention towards the significance of the country-particular institutional surroundings in managerial ownership-associated organization harms.

Kale and Noe (1990) suggested that "dividend acts as a signal of the stability of the firm's future cash flow". Brigham et al. (1996) suggested that dividends provide perhaps the best and most reliable signal and that "an increase in dividend signals management's confidence level would be strong towards the future earnings will be strong enough to support new and higher dividend and vice versa" Brigham et al. (1996). Nissim and Ziv (2001) documented that the dividend policy is much important for business in many ways likewise; to retain their shareholder, predicting future earnings etc., but it depends on the top level management "how much they share their percentage of annual earnings to shareholders" through pay dividends. Amidu (2007) examined the relationship among return on assets, return on equity, sale growth and dividend payments in their research and conclude that dividend payments significantly affect the performance of firm over the next years and also found positive and significant relation among studded variable with dividend payout. The results also revealed a statistically significant relationship between profitability and dividend payout ratio. Kouki and Guizani (2009) conduct a study on Tunisian companies and they conclude that dividend payout is highly associated and affected by ownership concentration. 
Aggrawal and Kyaw (2010) conduct a study on dividend payout and capital structure issues and conclude that leverage and dividend policy both are alternative apparatus to control the 'agency's cost' and improves the firm financial performance. Study also suggests that pay dividend to shareholders may also improve the level of activity of the organization which eventually increases the income level and have more retained earnings to achieve the set standards.

Ali and Ullah (2011) conduct a research on dividend policy and ownership structure on the data set of Pakistani listed firm from 2002-2006 and conclude that cash dividend level is higher where the owners' presence in the board of directors is higher. Results point out that managerial ownership appears to have a visible and significant effect on dividend payout. Ajanthan (2012) conduct a study on Sri Lanka hotel industry to measure the relation between one of the governance variable 'board independence' with dividend payout policy and conclude that there is a positive significant relationship between them. Another study conducted by Abor and Fiador (2013) also concludes a positive significant relation between board independence and dividend payout ratio employed the data set of Egyptian companies. Shehu (2015) documented that in their research conduct on Malaysian listed firms for small data set 2013 and conclude that a significant positive impact on dividend payout ratio. This study examines the relationship among corporate governance, capital structure, dividend policy and firm performance directly and indirectly in Pakistani listed firm on Karachi Stock Exchange considers as emerging economy. Furthermore, this study partially fill the gap by examining the mediating role of capital structure and dividend policy while corporate governance effecting the firm's performance. It elaborates the direct and indirect effects of corporate governance towards financial decisions and firm's performance which eventually considered as output at the end of financial year.

\section{Hypotheses}

Following hypotheses to be tested for this study:

$\mathbf{H}_{1}$ : Corporate governance measures have positive effects on capital structure of firm.

$\mathbf{H}_{2}$ : Corporate governance measures have positive effects on dividend policy of firm.

$\mathbf{H}_{3}$ : Corporate governance measures have positive effects on firm performance.

$\mathbf{H}_{4}$ : Capital structure of firm has positive effects on firm performance.

$\mathbf{H}_{5}$ : Dividend policy of firm has positive effects on firm performance. 


\section{HYPOTHESIZED RESEARCH MODEL}

Figure 1. Hypothesized Research Model

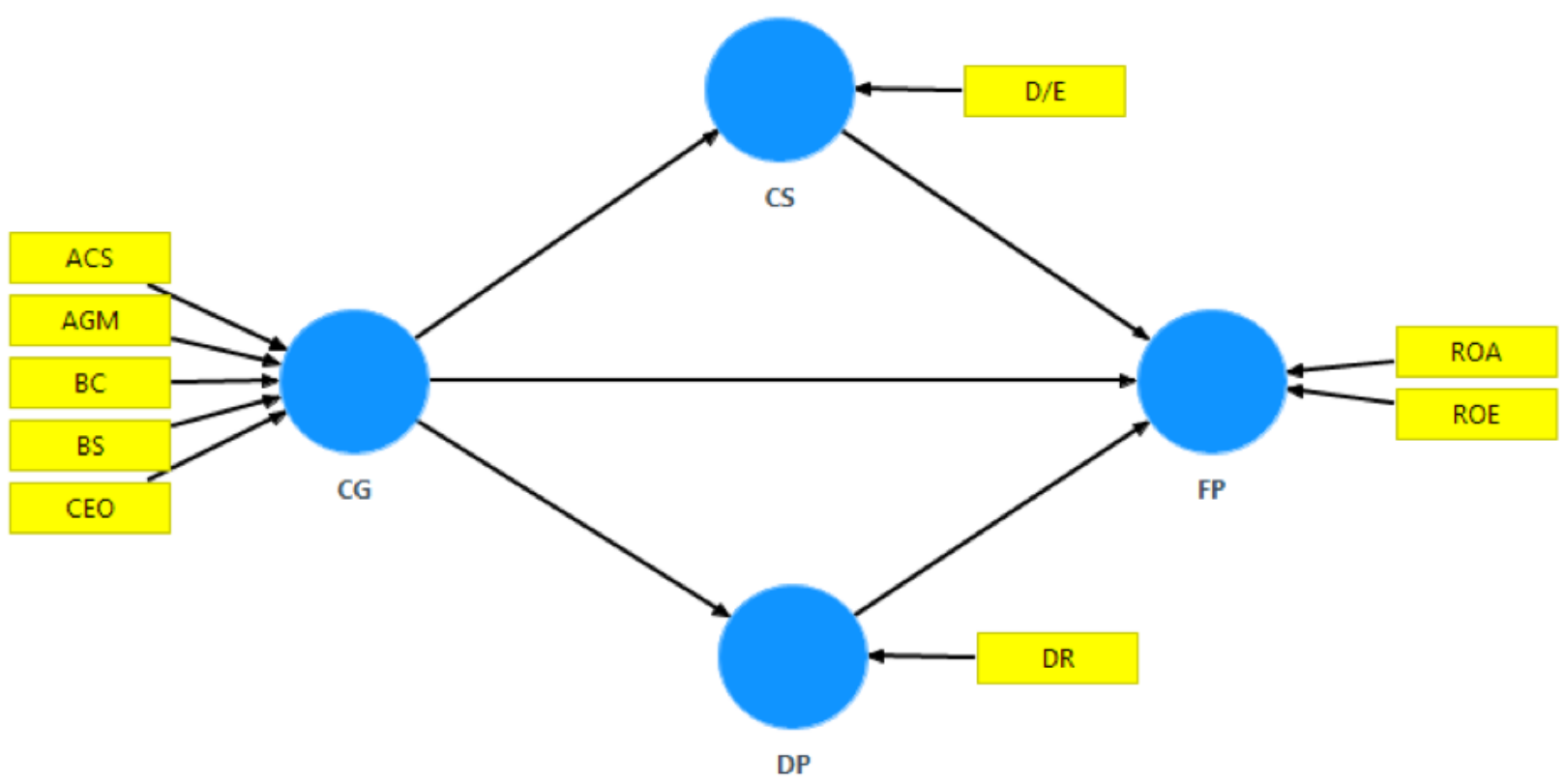

\section{METHODOLOGY AND DATA COLLECTION}

\section{Overall Population and Sample Size}

The archival financial and non-financial data of the firms gathered from Karachi Stock Exchange (KSE) which is the prime stock exchange of Pakistan. On behalf of this research study financial institutions such as Banks, DFIs, Leasing Companies, Insurance Companies, Modaraba Companies, Exchange Companies, and Mutual Funds were not included in the sample size due to entirely different assets allocation from other industrial firms. In this way all financial companies were excluded and the population reached to only non-financial listed firms out of which stratified random sample to be illustrated for analysis. Seven key sectors having hundred peer firms are included in this study, which enhances the value of study and its analysis. Given below the sector wise distribution of companies for sample size:

Table 1. Sector Wise Classification (2006-2011)

\begin{tabular}{c|l|c|c}
\hline No. & \multicolumn{1}{c}{ Sectors } & Number of Firms & Years 2006-2011 \\
\hline 1 & Cement & 15 & 90 \\
\hline 2 & Coke and Refined Petroleum Products & 9 & 54 \\
\hline 3 & Sugar & 15 & 90 \\
\hline 4 & Textile & 21 & 126 \\
\hline 5 & Fuel \& Energy & 13 & 78 \\
\hline 6 & Information, Communication \& transport Services & 11 & 66 \\
\hline 7 & Motor vehicles, trailers and auto parts & 16 & 96 \\
\hline Total & & $\mathbf{1 0 0}$ & $\mathbf{6 0 0}$ \\
\hline
\end{tabular}

Source: (Balance Sheet Analysis) 


\section{Data Collection}

The given research study is quantitative and based on the secondary and panel data which is generally collected from publicly listed companies. Only those firms are included in sample which remain listed and performed operations during the study period and the data was available for all of the years. The annual reports for the period of 2006-2011 were gathered through companies included in sample size. The data is extracted from the financial statements of these firms using Balance Sheet Analysis (BSA) published by State Bank of Pakistan (SBP).

\section{Data Analysis}

For this study, data sets are analyzed through SPSS, and SEM-PLS. To test the hypothesis of the relationships; Structural equation modeling based on cross-lagged analysis used to assess the models. Cross-lagged path analysis is basically designed for panel data which were collected for same individual more than one times. As well crosslagged path analysis is widely used to conclude causal relationship in the data from longitudinal research design.

\section{Structural Equation Models Development}

Based on the theoretical discussion this study is expected a significant and positive relation among the studded variables, corporate governance, capital structure, dividend policy and firm performance in the above stated hypotheses. This study tests the above mentioned hypotheses on the basis of measurement, structural and regression models.

\section{Measurement Models}

In the hypothesized structural model all indicators shown in squares build and influence their respective latent constructs shown in circles. These latent constructs can be measured in mathematical terms such as:

$$
\begin{aligned}
& \zeta=X_{1} \beta_{1}+X_{2} \beta_{2}+X_{3} \beta_{3}+X_{4} \beta_{4}+X_{5} \beta_{5}+\varepsilon \\
& \xi^{1}=y_{1} \beta_{2}+\varepsilon \\
& \xi^{2}=y_{2} \beta_{2}+\varepsilon \\
& \delta=y_{3} \beta_{3}+y_{4} \beta_{4}+\varepsilon
\end{aligned}
$$

\section{Structural Models}

The first hypothesis influence of latent exogenous variables, corporate governance measures $(\zeta)$ on latent endogenous variables, capital structure $\left(\xi^{1}\right)$ would be measured through:

$$
\text { Hypothesis 1: } \quad \mathrm{CG} \rightarrow \mathrm{CS} \quad \xi^{1}=\zeta_{1} \beta_{1}+\varepsilon
$$

The second hypothesis influence of latent exogenous variables, corporate governance measures $(\zeta)$ on latent endogenous variables, dividend policy $\left(\xi^{2}\right)$ would be measured through:

$$
\text { Hypothesis 2: } \quad \mathrm{CG} \rightarrow \mathrm{DP} \quad \xi^{2}=\zeta_{1} \beta_{1}+\varepsilon
$$

The third hypothesis influence of latent exogenous variables, corporate governance measures $(\zeta)$ on latent endogenous variables, firm performance $(\delta)$ would be measured through:

$$
\text { Hypothesis 3: } \quad \mathrm{CG} \rightarrow \mathrm{FP} \quad \delta=\zeta_{1} \beta_{1}+\varepsilon
$$

In this way the forth hypothesis influence of capital structure $\left(\xi^{1}\right)$ on firm performance $(\delta)$ would be measured through:

$$
\text { Hypothesis 4: } \quad \mathrm{CS} \rightarrow \mathrm{FP} \quad \delta=\xi^{1}{ }_{1} \beta_{1}+\varepsilon
$$


In this way the fifth and last hypothesis influence of dividend policy $\left(\xi^{2}\right)$ on firm performance $(\delta)$ would be measured through:

$$
\text { Hypothesis 5: } \quad \text { DP } \rightarrow \text { FP } \quad \delta=\xi^{2}{ }_{1} \beta_{1}+\varepsilon
$$

While the effects of corporate governance, capital structure and dividend policy on firm performance would be calculated through:

$$
\mathrm{FP}=\alpha+(\mathrm{CG})_{1 \beta 1}+(\mathrm{CS})_{2 \beta 2}+(\mathrm{DP})_{3 \beta 3}+\varepsilon \quad \delta=\zeta_{1} \beta_{1}+\xi_{2}^{1}{ }_{2} \beta_{2}+\xi^{2}{ }_{3} \beta_{3}+\varepsilon
$$

\begin{tabular}{|c|c|c|c|}
\hline Variables & Symbols & Acronyms & Measurements \\
\hline Corporate Governance & $\mathrm{Z}$ & CG & Independent \\
\hline Board Size & $\chi_{1}$ & BS & $\begin{array}{l}\text { Total number of directors on the board including chairman and chief } \\
\text { executive officer. }\end{array}$ \\
\hline Board Composition & $\chi_{2}$ & $\mathrm{BC}$ & $\begin{array}{l}\text { The proportion of internal and external directors excluding chairman and } \\
\text { chief executive officer to the total number of directors on the board. }\end{array}$ \\
\hline CEO Duality & $\chi_{3}$ & $\mathrm{CEO}$ & $\begin{array}{l}\text { A dummy variable equal to } 1 \text { if CEO also holds the Board Chairman } \\
\text { position and } 0 \text { otherwise. }\end{array}$ \\
\hline Audit Committee Size & $\chi_{4}$ & $\mathrm{ACS}$ & Total number of directors on the audit committee. \\
\hline Annual General Meetings & $\chi_{5}$ & AGM & Total number of meetings held in a year \\
\hline Capital Structure & $\xi^{1}$ & CS & Mediator \\
\hline Debt to Equity Ratio & $\mathrm{y}_{1}$ & $\mathrm{D} / \mathrm{E}$ & Total Liabilities / Shareholder's Equity \\
\hline Dividend Policy & $\xi^{2}$ & DP & Mediator \\
\hline Dividend Ratio & $\mathrm{y}_{2}$ & DR & (Net Profit before Tax - Tax Provision) / Total Amount of Dividend \\
\hline Firm Performance & $\delta$ & FP & Dependent \\
\hline Return on Assets & $\mathrm{y}_{3}$ & ROA & Net Income before Tax / Average of Total Assets \\
\hline Return on Equity & $\mathrm{y}_{4}$ & ROE & Net Income before Tax / Average of Shareholder's Equity \\
\hline
\end{tabular}

Table 2. Description of Exogenous and Endogenous Variables

\section{DATA ANALYSIS AND EMPIRICAL RESULTS}

Table 3. Descriptive Statistics

\begin{tabular}{c|c|c|c|c|c|c|c|c}
\hline & Minimum & Maximum & Mean & Std. Dev. & \multicolumn{2}{c|}{ Skewness } & \multicolumn{2}{c}{ Kurtosis } \\
\hline & Statistic & Statistic & Statistic & Statistic & Statistic & Std. Error & Statistic & Std. Error \\
\hline BS & 7.00 & 14.00 & 9.7000 & 1.74214 & .558 & .100 & -.836 & .199 \\
\hline BC & 5.00 & 12.00 & 8.1317 & 1.882244 & .482 & .100 & -1.059 & .199 \\
\hline CEO & .00 & 1.00 & .4333 & .49595 & .271 & .100 & -1.934 & .199 \\
\hline ACS & 2.00 & 6.00 & 3.5583 & .81304 & .896 & .100 & -.582 & .199 \\
\hline AGM & 2.00 & 59.00 & 11.1917 & 9.72896 & 2.300 & .100 & 5.791 & .199 \\
\hline D/E & -292.32 & 795.70 & 4.7422 & 49.66205 & 13.085 & .100 & 206.356 & .199 \\
\hline FR & -500.01 & 79.87 & 1.5695 & 21.38435 & -21.462 & .100 & 507.802 & .199 \\
\hline ROE & 823.35 & 442.49 & 9.4311 & 66.97624 & -4.339 & .100 & 51.497 & .199 \\
\hline Valid N & 600 & & & & & & & \\
\hline
\end{tabular}




\section{Correlation Matrix}

\begin{tabular}{|c|c|c|c|c|c|c|c|c|c|}
\hline & BS & BC & CEO & ACS & AGM & $\mathbf{D} / \mathbf{F}$ & DR & ROA & ROF \\
\hline BS & 1 & & & & & & & & \\
\hline BC & $.964^{* *}$ & 1 & & & & & & & \\
\hline CEO & $.160^{* *}$ & $.398^{* *}$ & 1 & & & & & & \\
\hline ACS & $.384^{* *}$ & $.333^{* *}$ & $-.092^{*}$ & 1 & & & & & \\
\hline AGM & -.066 & .053 & $.240^{* *}$ & .030 & 1 & & & & \\
\hline $\mathbf{D} / \mathbf{E}$ & -.026 & -.027 & -.019 & .030 & -.003 & 1 & & & \\
\hline DR & -.035 & -.042 & -.036 & .026 & -.058 & -.039 & 1 & & \\
\hline ROA & .022 & -.014 & -.136 & $.125^{* *}$ & -.053 & -.062 & $.206^{* *}$ & 1 & \\
\hline ROE & .027 & .042 & .064 & .052 & .007 & $-.175^{* *}$ & $.186^{* *}$ & $.405^{* *}$ & 1 \\
\hline
\end{tabular}

Source: SPSS output

**Correlation is significant at the 0.01 level ( 2 tailed)

*Correlation is significant at the 0.05 level ( 2 tailed)

Table 3 explains the detail summary of descriptive statistics of all variables included in this study which consists of independent, mediating and dependent variables. Table 4 represents the correlation matrix of each variable. The result shows that ROE and D/E are negatively correlated at -.175 respectively, while ROE as a dependent variable have positive relationship with all other explanatory variables. The correlation of ROA of all non-financial sectors with BS, ACS and D/E shows positive correlation at .022, .125 and .206, ROA with all other independent variables have negative correlation. DR of selected non-financial companies shows negative correlation with explanatory variables, other than ACS which shows positivity at point .026. On the other hand the Pearson correlations of all corporate governance indicators with each other are positive except BS with AGM and ACS with CEO at -.006 and -.092 , the variance-covariance among variables is too high for BS and BC which is on the higher side .964. This indicates that both these variables represent the same financially viable phenomenon.

\section{KMO Measures Of Sample Adequacy (MSA)}

The Kaiser-Meyer-Olkin measures test is the analysis part of our study it is vital for factor analysis method. Bhaduri (2002) also explains the importance of factor analysis technique as the statistical tool. The technique depends on twofold. Extracting the factors based on KMO MSA rule and regress the extracted factors against dependent variables. KMO Measures of sample adequacy (MSA) value 0.379 demonstrates that data. Both of these indicators apparently show satisfactory outcome for performing factor analysis.

Table 5. KMO and Bartlett's Test

\begin{tabular}{l|c|c}
\hline Kaiser-Meyer-Olkin Measure of Sampling Adequacy & .379 \\
\hline \multirow{3}{*}{ Barlett's Test of Sphericity } & Approx. Chi-Square & $3.120 \mathrm{E} 3$ \\
\cline { 2 - 3 } & Df & 36 \\
\hline Source SPSS output & Sig. & .000 \\
\hline
\end{tabular}

Source: SPSS output 
Table 6. Varimx Rotated Component Matrix ${ }^{\mathrm{a}}$

\begin{tabular}{|c|c|c|c|}
\hline & \multicolumn{3}{|c|}{ Component } \\
\hline & 1 & 2 & 3 \\
\hline Board Size & .951 & -.027 & .097 \\
\hline Board Composition & .930 & -.034 & .292 \\
\hline CEO Duality & .187 & -.033 & .811 \\
\hline Audit committee Size & .621 & .089 & -.304 \\
\hline Annual General Meetings & -.055 & -.010 & .626 \\
\hline Debt to Equity Ratio & .033 & -.377 & -.237 \\
\hline Dividend Ratio & -.030 & .520 & -.111 \\
\hline Return an Assets & 0.78 & .738 & -.226 \\
\hline Return on Equity & .040 & .793 & .138 \\
\hline$\%$ of Variance in Rotation & 24.462 & 17.744 & 15.276 \\
\hline Eigenvalues: & 2.285 & 1.632 & 1.256 \\
\hline
\end{tabular}

Source: SPSS output

Extraction Method: Principal Component Analysis.

Rotation Method: Varimax with Kaiser Normalization.

According to above table factor 1 is highly loaded with board size, board composition and audit committee. Board size and composition have no more diversity and balances the power of the board and enlarges the controlling power of chairman or CEO and ensures no more transparency of transactions in firms. Therefore this study considers board size as a factor. Factor 2 is highly loaded with return on equity, return on assets and dividend ratio. Return on equity and return on assets are positively related and having important value for the firm. Again return on equity and return on assets determines the independent functioning capability of the firm. The higher board paves the way for more independent thinking and decision for to improve the performance on the basis of returns after considering financing decisions. Therefore this study considers both return on equity and return on assets as the factor. Factor 3 is highly loaded with CEO duality and annual general meetings. They both are considered important for higher director's shareholding position and may attract fewer institutions to hold or purchase new shares of the company. Therefore this study considers the CEO duality and annual general meetings as a factor. Factor one account for 24.462 of the variance, second 17.744 third 15.276 , a total is 57.482 of overall variance.

\section{Partial Least Square Analysis}

Partial Least Squares (PLS) technique based models analyzes and interprets into two ways. First, Measurement model evaluation and then structural model evaluation. The relationship between observed variables and latent variables (factors) evaluated by measurement model. Structural model specifies relations between latent constructs. Estimating and analyzing the path coefficients between the constructs test through structural model. Path coefficients are indicators of the model's predictive ability.

\section{RESULTS AND DISCUSSION OF MEASUREMENT AND STRUCTURAL MODELS}

Analysis of the measurement model attempts to confirm the reliability and validity of all latent variables that are included in the structural model. To estimate reliability and validity of the measurement model correctly reference must be made either the indicator is formative or reflective. In case of reflective indicators item reliability, construct reliability, convergent validity and discriminant validity should be checked.

While in case of formative indicators, loadings are misleading because correlation between indicators within a construct is neither required nor taken into account while estimating the construct parameter, thus no need to check item reliability. It makes no sense to compare loadings among indicators within a construct, accordingly making the internal consistency unnecessary. Rossiter (2002) and Diamantopoulos and Siguaw (2006) are of the view that no dimensionality and reliability test are performed on formative indicators because of factorial unity and internal consistencies are not relevant thus composite reliability measure Cronbach's Alpha is not desirable. While, Andreev, Heart, Maoz and Pliskin (2009) conclude that construct reliability of formative indicators should be performed through test of Variance Inflation Factor (VIF) Multicollinearity and indicator validity through their statistical significance. Interpretation of a construct with formative indicators should be based on the weight of each indicator 
(Chin, 1998). Like canonical correlation (multivariate statistical model) these weights allow understanding the contribution of each indicator in emerging the construct. However potential threat of multicollinearity should be removed before running the structural model (Diamantopoulos and Winklhofer, 2001).

In partial least square method, first item that PLS provides to determine how well the model fits the hypothesized relationship is the squared multiple correlations $\left(\mathrm{R}^{2}\right)$ for each dependent construct. To measure the relationship and their effects among CG, CS and DP on FP, it seems beneficial to employ cross lagged modeling based on SEM-PLS to examine the impact of explanatory variable to dependent variable. The cross lagged analysis based on structural equation modeling gives an estimation of the effects of CG on CS, DP and FP. It would be written as follow:

$$
\delta=\zeta_{1} \beta_{1}+\xi^{1}{ }_{2} \beta_{2}+\xi^{2}{ }_{3} \beta_{3}+\varepsilon
$$

From the right side $\left(\beta_{1}\right)$ specifies the beta and path coefficients of the latent endogenous variable $\left(\zeta_{1}\right)$ used for Corporate Governance. The other are $\left(\beta_{2}, \beta_{3}\right)$ specifies beta and path coefficients of second and third latent endogenous variables $\left(\xi_{2}^{1}\right)$ for Capital Structure while $\left(\xi_{3}^{2}\right)$ for Dividend Policy. While at left side $(\delta)$ of the equation specifies the outcome variable for Firm Performance and $(\varepsilon)$ is the error term. In PLS based SEM, strength of hypothesis formulated in this research study is generally measured through analyzing path coefficient $(\beta)$. In order to have the statistical significance of path coefficients ( $\beta$ ) a PLS algorithm and bootstrapping techniques through Smart-PLS on the 600 sample data with replacement were applied the summary of required results given in the tables below:

Table 7. Model-1 Summary and Hypothesis Testing

\begin{tabular}{c|l|c|c|c|c|c}
\hline & Relationships & Path Coefficients & $\mathbf{R}^{2}$ & T-Value & Sig. & Hypothesis \\
\hline $\mathrm{H}_{1}$ & $\mathrm{CG} 1 \rightarrow$ CS1 & 0.375 & 0.979 & 2.207 & 0.028 & Confirmed \\
\hline $\mathrm{H}_{1}$ & $\mathrm{CG} 1 \rightarrow \mathrm{CS} 1$ & 0.342 & 0.958 & 2.207 & 0.028 & Confirmed \\
\hline $\mathrm{H}_{3}$ & $\mathrm{CG} 1 \rightarrow \mathrm{FP} 2$ & 0.259 & 0.656 & 1.404 & 0.053 & Confirmed \\
\hline $\mathrm{H}_{3}$ & $\mathrm{CG} 3 \rightarrow$ FP4 & 0.182 & 0.568 & 2.270 & 0.017 & Confirmed \\
\hline $\mathrm{H}_{1}$ & $\mathrm{CG} 4 \rightarrow \mathrm{CS} 4$ & 0.357 & 0.947 & 2.350 & 0.019 & Confirmed \\
\hline $\mathrm{H}_{3}$ & $\mathrm{CG} 4 \rightarrow$ FP5 & 0.132 & 0.454 & 2.218 & 0.018 & Confirmed \\
\hline $\mathrm{H}_{4}$ & $\mathrm{CS} 5 \rightarrow$ FP6 & 0.276 & 0.742 & 1.677 & 0.051 & Confirmed \\
\hline $\mathrm{H}_{4}$ & $\mathrm{CS} 5 \rightarrow$ FP6 & 0.234 & 0.741 & 1.677 & 0.051 & Confirmed \\
\hline
\end{tabular}

Source: SmartPLS-3 output

From factor one variables the above table shows list of path coefficients $(\beta), \mathrm{R}^{2}$ along with t-values and significance from Model-1a for the period of 2006 to 2011. Which shows that CG effects on CS, CG effects on FP and CS effects on FP with time lag of one year have higher r-squared values $(97 \%, 65 \%$, and $74 \%)$, on the basis of r-squared values and positive path coefficients accepting $\mathrm{H}_{1}, \mathrm{H}_{3}$ and $\mathrm{H}_{4}$ of the study. From factor two variables the above table shows list of path coefficients $(\beta), \mathrm{R}^{2}$ along with $\mathrm{t}$-values and significance from Model- $1 \mathrm{~b}$ for the period of 2006 to 2011. Which shows that CG effects on CS, CG effects on FP and CS effects on FP with time lag of one year have higher r-squared values $(95 \%, 45 \%$ and $74 \%$ ), on the basis of r-squared values and positive path coefficients accepting $\mathrm{H}_{1}, \mathrm{H}_{3}$ and $\mathrm{H}_{4}$ of the study. On the other hand CG effects on CS for the same year have high path coefficient with higher $r^{2}$ and significance level, while CG effects on the next year of performance positively and shows positive results which indicates that if firm following good corporate governance practices it might give better results for the coming financial year that is demonstrated by performing PLS on the bases of one cross-lagged analysis. 
Table 8. Model-2 Summary and Hypothesis Testing

\begin{tabular}{c|l|c|c|c|c|c}
\hline & Relationships & Path Coefficients & R2 & T-Value & Sig. & Hypothesis \\
\hline $\mathrm{H}_{2}$ & CG2 $\rightarrow$ DP2 & 0.370 & 0.749 & 1.861 & 0.050 & Confirmed \\
\hline $\mathrm{H}_{3}$ & $\mathrm{CG} 1 \rightarrow$ FP2 & 0.268 & 0.511 & 1.902 & 0.010 & Confirmed \\
\hline $\mathrm{H}_{5}$ & $\mathrm{DP} 4 \rightarrow$ FP5 & 0.062 & 0.457 & 1.824 & 0.070 & Confirmed \\
\hline $\mathrm{H}_{3}$ & $\mathrm{CG} 3 \rightarrow$ FP4 & 0.322 & 0.866 & 1.403 & 0.075 & Confirmed \\
\hline $\mathrm{H}_{2}$ & $\mathrm{CG} 5 \rightarrow$ DP5 & 0.427 & 0.970 & 1.943 & 0.041 & Confirmed \\
\hline $\mathrm{H}_{5}$ & $\mathrm{DP} 5 \rightarrow$ FP6 & 0.350 & 0.622 & 1.950 & 0.039 & Confirmed \\
\hline $\mathrm{H}_{3}$ & $\mathrm{CG} 3 \rightarrow$ FP4 & 0.372 & 0.836 & 1.403 & 0.075 & Confirmed \\
\hline $\mathrm{H}_{2}$ & $\mathrm{CG} \rightarrow \mathrm{DP} 2$ & 0.375 & 0.807 & 1.861 & 0.050 & Confirmed \\
\hline $\mathrm{H}_{5}$ & DP5 $\rightarrow$ FP6 & 0.358 & 0.627 & 1.950 & 0.039 & Confirmed \\
\hline
\end{tabular}

Source: SmartPLS-3 output

From factor one variables the above table shows list of path coefficients $(\beta), \mathrm{R}^{2}$ along with $\mathrm{t}$-values and significance from Model-2a for the period of 2006 to 2011. Which shows that CG effects on DP, CG effects on FP and DP effects on FP with time lag of one year have higher r-squared values ( $74 \%, 86 \%$ and $62 \%$ ), on the basis of r-squared values and positive path coefficients accepting $\mathrm{H}_{2}, \mathrm{H}_{3}$ and $\mathrm{H}_{5}$ of the study. On the other hand CG effects on DP for the same year have high path coefficient with higher $\mathrm{r}^{2}$ and significance level, while CG effects on the next year of performance positively and shows positive results.

From factor two variables the above table shows list of path coefficients $(\beta), \mathrm{R}^{2}$ along with t-values and significance from Model-2b for the period of 2006 to 2011. Which shows that CG effects on DP, CG effects on FP and DP effects on FP with time lag of one year have higher r-squared values $(80 \%, 83 \%$ and $62 \%)$, on the basis of r-squared values and positive path coefficients accepting $\mathrm{H}_{1}, \mathrm{H}_{3}$ and $\mathrm{H}_{4}$ of the study. Results of the study based on cross-lagged analysis in line with prior studies which were examined the relationship of these variables separately. The contribution of this study is into two folded; First, corporate governance is considered as the way to improving firm performance (Hart, 1995; Fama and Jensen, 1983) and it is also considered as the way that provide suppliers of finance with some protection in regards to their investment policies (Shleifer and Vishny 1997; Rahman 2006 and Randers et al., 2010).

\section{CONCLUSION}

Corporate governance has a growing importance for stability among financial and social goals all around the Globe; corporate governance code in Pakistan has also developed for listed companies to certify accountability of transactions and better transparency. Corporate collapses like; 'Enron', 'WorldCom', and 'One-Tel' have encouraged the requirement for strong governance practices both in developed and enveloping state. Pakistani firms are family controlled since the earlier period and ownership is very concentrated. The relationship of corporate governance variables has been generally researched but still there are no appropriate results for end conclusions. In this research a large number of corporate governance mechanisms are taken for evaluating the relationship among governance practices with capital structure, dividend policy and firms financial performance.

This study investigate the effects of corporate governance practices on capital structure decisions, dividend payout policy and firm performance of hundred peer firms' listed as non- financial companies in Pakistan for the period of 2006 to 2011. The outcome suggests that corporate governance mechanisms have positive significant relationship with financial decisions and firm performance indicators. Our analysis is formed in different statistical techniques including structural equation modeling (SEM) to check structural link among all variables. Analyses were performed through one year time lag for examining the hypothesis. Our study relates to the corporate governance internal practices, financing decision, dividend payout and financial ratios.

This study has summarized the internal corporate governance mechanisms and their relationship with capital structure, dividend policy and firm performance. It add value to the literature and open new dimensions for further studies, in which both internal and external corporate governance mechanisms and practices would include along with their effects on capital structure, dividend policy and firm performance proxies. Predominantly this study contains peer firms governance practices and their behavior while making financial decisions to enhance their 
performance which may increases the value of firm. Peer firms play an essential role in determining a number of corporate policies, and existing evidence suggests that the behavior of peer firms may matter for financing structure.

Corporate governance aims to control the management activities for the best interest of shareholder requiring the rights and responsibilities among different related parties in the organization. According to the literature review and previous studies corporate governance literature has two stands. Firstly, it considers guiding and improving the firm performance (Hart, 1995; Fama \& Jensen, 1983); and the second considers providing suppliers of finance with some protection in regards to their investment policies (Rahman, 2006; Shleifer \& Vishny, 1997). The second thought has become the center of contemporary corporate governance studies since the collapse and scandals of the large corporation in developed economies. This research study falls into the both school of corporate governance literature, and it examined the effect of corporate governance mechanisms on financial policies such as capital structure and dividend policy, as well examines the effect of this whole phenomenon on firm performance.

\section{ACKNOWLEDGEMENT}

This research is supported by School of International Education, Xidian University, Xi'an, Shaanxi, P. R. China.

\section{AUTHOR BIOGRAPHIES}

Rizwan Ali is currently pursuing his PhD from the School of International Education, Xidian University, Xi'an, Shaanxi, P. R. China. He has more than 5 years of teaching and research experience at the university level. He is also serving as a Lecturer of finance at Lahore Business School, The University of Lahore. His research interest includes corporate finance, corporate governance, corporate social responsibility and financial integration. E-mail: rizwanalilbs@outlook.com (Corresponding Author)

Dr. Yanping Liu, Professor of Finance in School of Economics and Management, Xidian University, Xi'an, Shaanxi, P. R. China. He has over 25 years of teaching and research experience and published several articles in high influence national and international journals. His research interest includes economic development, organization structure development and organization corporate value.

Gul Rukh is currently doing her PhD in Management Sciences from the Lahore Business School, The University of Lahore. Her research interest includes corporate governance; firm performance and social development.

\section{REFERENCES}

Abdullah, H. N. M., Ahmad, Z., \& Roslan, S. (2012). The influence of ownership structure on the firms dividend policy based Lintner model. International Review of Business Research Papers, 8(6), 71-88.

Abor \& Fiador. (2013) Does corporate governance explain dividend policy in sub-Saharan Africa?. International Journal of Law and Management, 55(3), 201-225.

Abor, J. (2005). The effect of capital structure on profitability: an empirical analysis of listed firms in Ghana. Journal of Risk Finance, The, 6(5), 438-445.

Adjaoud, F., \& Ben-Amar, W. (2010). Corporate governance and dividend policy: shareholders' protection or expropriation?. Journal of Business Finance \& Accounting, 37(5-6), 648-667.

Aggarwal, R., \& Kyaw, N. A. (2010). Capital structure, dividend policy, and multinationality: Theory versus empirical evidence. International Review of Financial Analysis, 19(2), 140-150.

Ajanthan, (2012), Corporate Governance and Dividend Policy: A Study of Listed Hotels and Restaurant Companies in Sri Lanka, International Journal of Management, IT and Engineering, 3 (12), 1-17.

Ali, S.Z. and Ullah, W. (2011). Impact of Ownership Structure on Dividend Policy of Firm: Evidence from Pakistan. International Proceedings of Economics Development and Research, 3, 22-27.

Amidu, M. (2007). How does dividend policy affect performance of the firm on Ghana stock Exchange. Investment Management and Financial Innovations, 4(2), 103-112.

Andreev, P., Heart, T., Maoz, H., \& Pliskin, N. (2009). Validating formative partial least squares (PLS) models: methodological review and empirical illustration. ICIS 2009 Proceeding paper 193.

Bhaduri, S. N. (2002). Determinants of corporate borrowing: some evidence from the Indian corporate structure. Journal of Economics and Finance, 26(2), 200-215.

Brigham, E. F., \& Gapenski, L. C. (1996). International financial management. Sea Harbor Drive: The Dryden Press. 
Bunkanwanicha, P., Gupta, J., \& Rokhim, R. (2008). Debt and entrenchment: evidence from Thailand and Indonesia. European Journal of Operational Research, 185(3), 1578-1595.

Cadbury, A. (1992). Report of the committee on the financial aspects of corporate governance (Vol. 1). Gee.

Chhibber, P. K., \& Majumdar, S. K. (1997). Foreign Ownership and Profitability: Property Rights, Strategic Control and Corporate Performance in Indian Industry.

Chin, W. W. (1998). The partial least squares approach to structural equation modeling. Modern methods for business research, 295(2), 295-336.

Diamantopoulos, A., \& Siguaw, J. A. (2006). Formative versus reflective indicators in organizational measure development: a comparison and empirical illustration. British Journal of Management, 17(4), 263-282.

Diamantopoulos, A., \& Winklhofer, H. M. (2001). Index construction with formative indicators: an alternative to scale development. Journal of marketing research, 38(2), 269-277.

Drobetz, W., Schillhofer, A., \& Zimmermann, H. (2004). Corporate governance and expected stock returns: Evidence from Germany. European Financial Management, 10(2), 267-293.

Ehikioya, B. I. (2009). Corporate governance structure and firm performance in developing economies: evidence from Nigeria. Corporate Governance, 9(3), 231-243.

Fama, E. F., \& Jensen, M. C. (1983). Agency problems and residual claims. Journal of law and Economics, 327-349.

Florackis, C., \& Ozkan, A. (2009). Managerial incentives and corporate leverage: evidence from the United Kingdom. Accounting \& Finance, 49(3), 531-553.

Gompers, P.A., Ishii, J.L. \& Metrick, A. (2003). Corporate Governance And Equity Prices. Technology, 107.

Gugler, K. (2003). Corporate governance, dividend payout policy, and the interrelation between dividends, R\&D, and capital investment. Journal of Banking \& Finance, 27(7), 1297-1321.

Haat, M. H. C., Rahman, R. A., \& Mahenthiran, S. (2008). Corporate governance, transparency and performance of Malaysian companies. Managerial Auditing Journal, 23(8), 744-778.

Hart, O. (1995). Corporate governance: some theory and implications. The economic journal, 678-689.

Hart, O., \& Moore, J. (1995). A theory of debt based on the inalienability of human capital (No. 3906). National Bureau of Economic Research.

Hu, A., \& Kumar, P. (2004). Managerial entrenchment and payout policy. Journal of Financial and Quantitative Analysis, 39(04), 759-790.

Hurdle, G. J. (1974). Leverage, risk, market structure and profitability. The Review of Economics and Statistics, 478-485.

Hwang, L. S., Park, K., \& Park, R. (2004). Do Firms with Good Corporate Governance Practices Pay More Dividends? Evidence from Korean Business Groups. working paper.

Javed, A. Y., Iqbal, R., \& Hasan, L. (2006). Corporate Governance and Firm Performance: Evidence from Karachi Stock Exchange [with Comments]. The Pakistan Development Review, 947-964.

Jensen, M. C. (1993). The modern industrial revolution, exit, and the failure of internal control systems. the Journal of Finance, 48(3), 831-880.

Jensen, M. C., \& Meckling, W. H. (1976). Theory of the Firm: Managerial Behavior, Agency Costs and Ownership Structure. Journal of Financial Economics, 3(4), 305-360.

Jiraporn, P., Kim, J. C., \& Kim, Y. S. (2011). Dividend payouts and corporate governance quality: An empirical investigation. Financial Review, 46(2), 251-279.

Kajola, S. O. (2008). Corporate governance and firm performance: The case of Nigerian listed firms. European Journal of Economics, Finance and Administrative Sciences, 14(14), 16-28.

Kale, J. R., \& Noe, T. H. (1990). Dividends, uncertainty, and underwriting costs under asymmetric information. Journal of Financial Research, 13(4), 265-77.

Klein, A. (1998). Firm Performance and Board Committee Structure 1. The Journal of Law and Economics, 41(1), 275-304.

Konzelmann, S., Wilkinson, F., Fovargue-Davies, M., \& Sankey, D. (2010). Governance, regulation and financial market instability: the implications for policy. Cambridge Journal of Economics, 34(5), 929-954.

Kouki, M. \& Guizani, M. (2009), European Journal of Scientific Research, Vol.25 No.1(2009), pp.42-53.

Kowalewski, O., Stetsyuk, I., \& Talavera, O. (2008). Does corporate governance determine dividend payouts in Poland?. PostCommunist Economies, 20(2), 203-218.

Lev, B. (1974). On the association between operating leverage and risk. Journal of financial and quantitative analysis, 9(04), 627-641.

Lima, B. F., \& Sanvicente, A. Z. (2013). Quality of Corporate Governance and Cost of Equity in Brazil. Journal of Applied Corporate Finance, 25(1), 72-80.

Magdalena, R. (2012). Influence of Corporate Governance on Capital Structure Decision: Evidence From Indonesian Capital Market. World Review of Business Research, 2(4,) 37-49.

Mehran, H. (1995). Executive compensation structure, ownership, and firm performance. Journal of financial economics, 38(2), 163-184.

Nissim, D., \& Ziv, A. (2001). Dividend changes and future profitability. The Journal of Finance, 56(6), 2111-2133.

Rahman, R. A. (2006). Effective corporate governance. University Publication Centre, Universiti Teknologi MARA.

Renders, A., Gaeremynck, A., \& Sercu, P. (2010). Corporate-Governance Ratings and Company Performance: A Cross-European 
Study. Corporate Governance: An International Review, 18(2), 87-106.

Rossiter, J. R. (2002). The C-OAR-SE procedure for scale development in marketing. International journal of research in marketing, 19(4), 305-335.

Saad, N. M. (2010). Corporate governance compliance and the effects to capital structure in Malaysia. International journal of economics and finance, 2(1), 105-114.

Shehu, M. (2015). Board Characteristics and Dividend Payout: Evidence from Malaysian Public Listed Companies. Research Journal of Finance and Accounting, 6 (1), 35-41.

Shleifer, A., \& Vishny, R. W. (1997). A survey of corporate governance. The journal of finance, 52(2), 737-783.

Thanatawee, Y. (2012). Ownership structure and dividend policy: Evidence from Thailand. International Journal of Economics and Finance, 5(1), p121.

Wen, Y., Rwegasira, K., \& Bilderbeek, J. (2002). Corporate governance and capital structure decisions of the Chinese listed firms. Corporate Governance: An International Review, 10(2), 75-83.

Wippern, R. F. (1966). Financial Structure and the Value of the Firm. The Journal of Finance, 21(4), 615-633. 


\section{ANNEXURE A}

\section{Cross-lagged Structural Models}

\section{Model 1A}

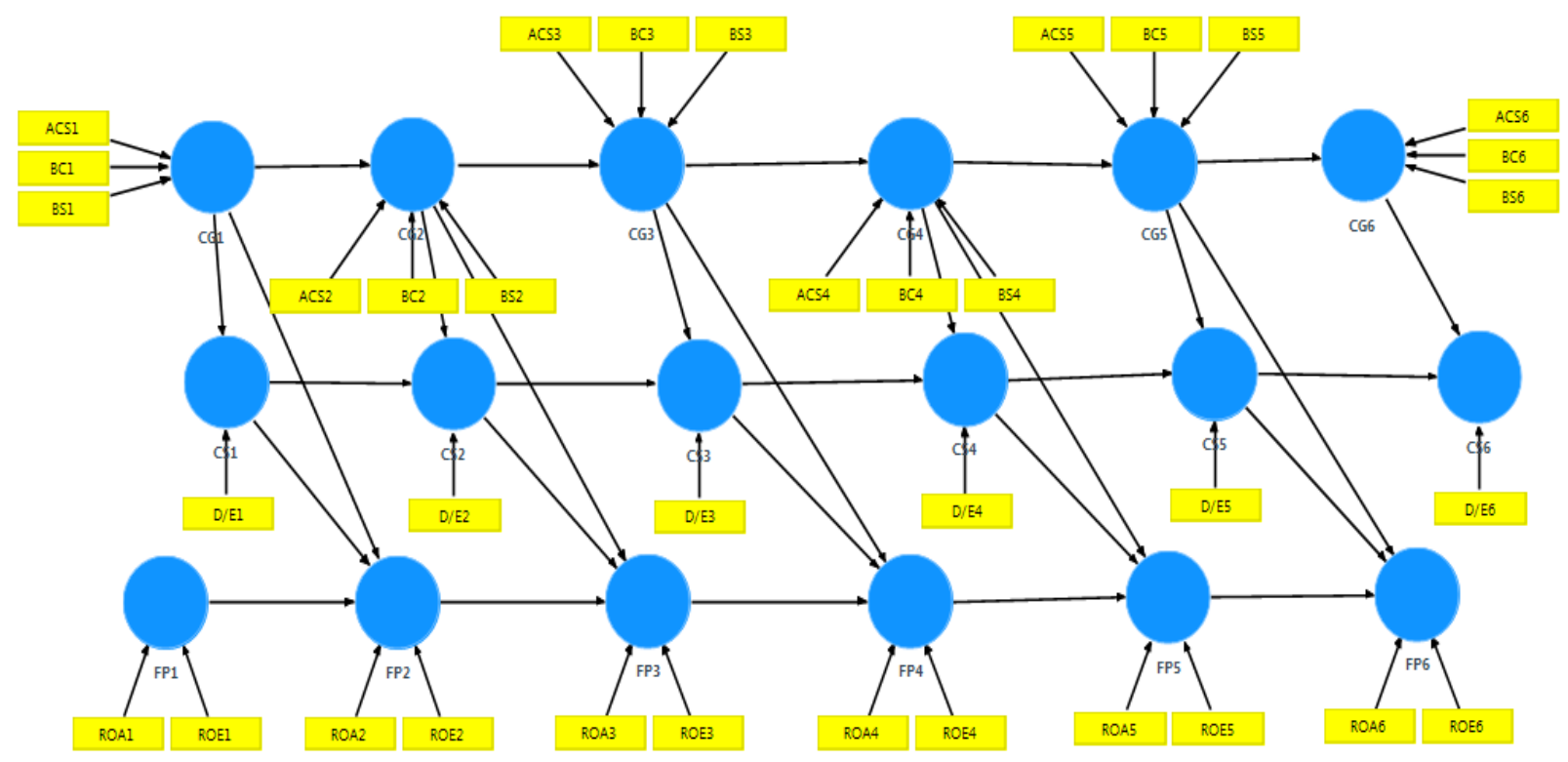

Model 1B

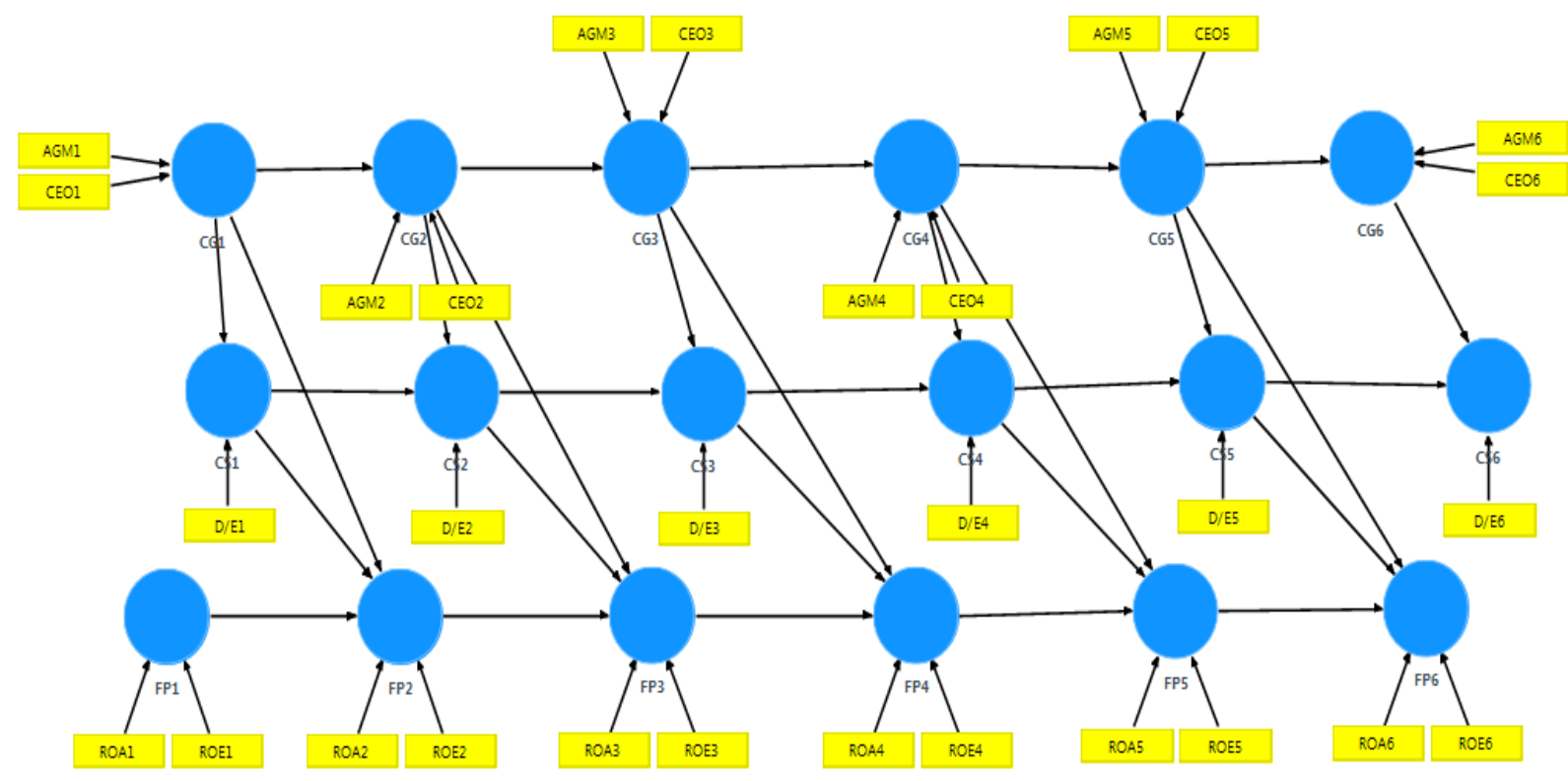




\section{Model 2A}

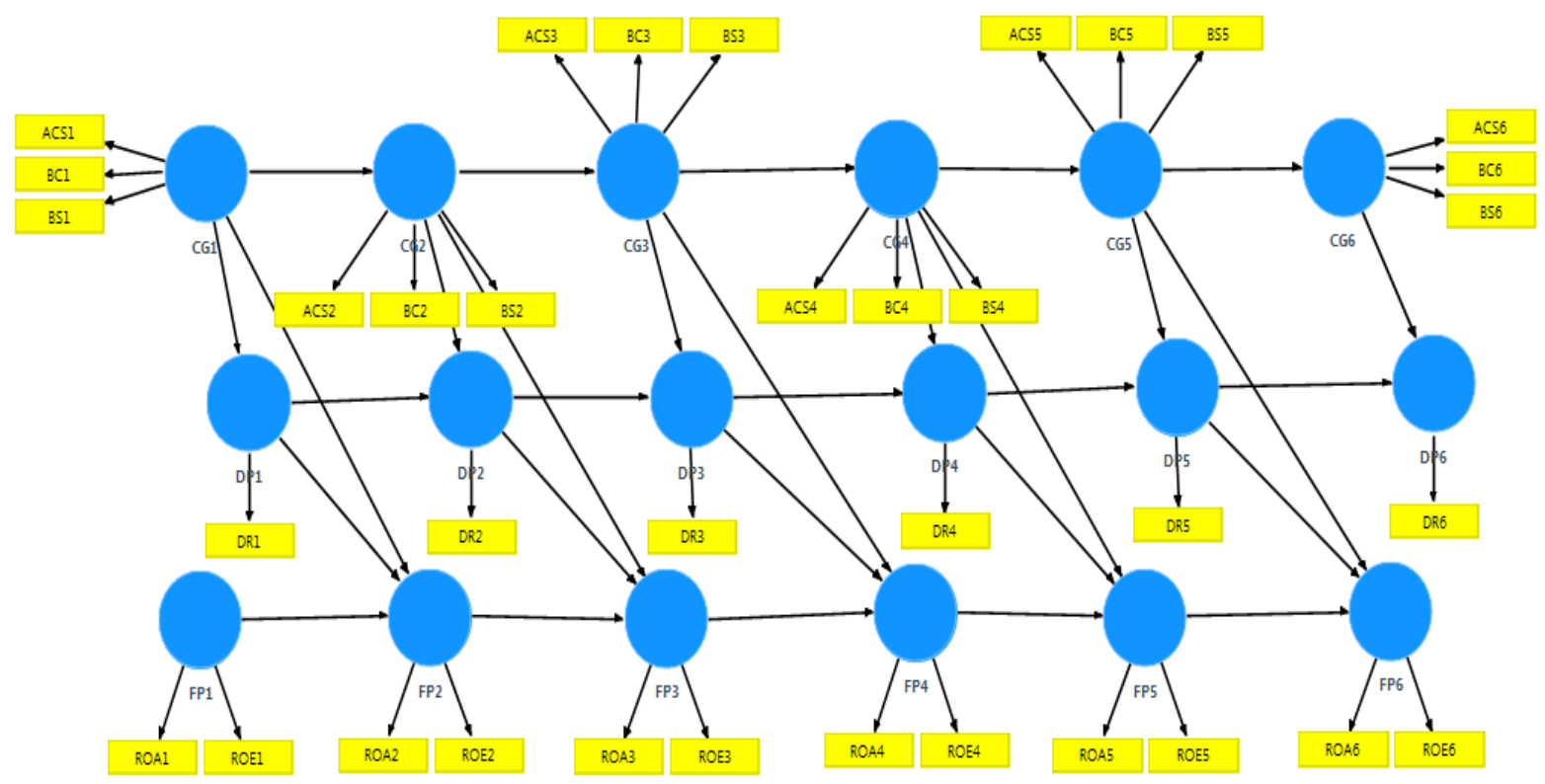

Model 2B

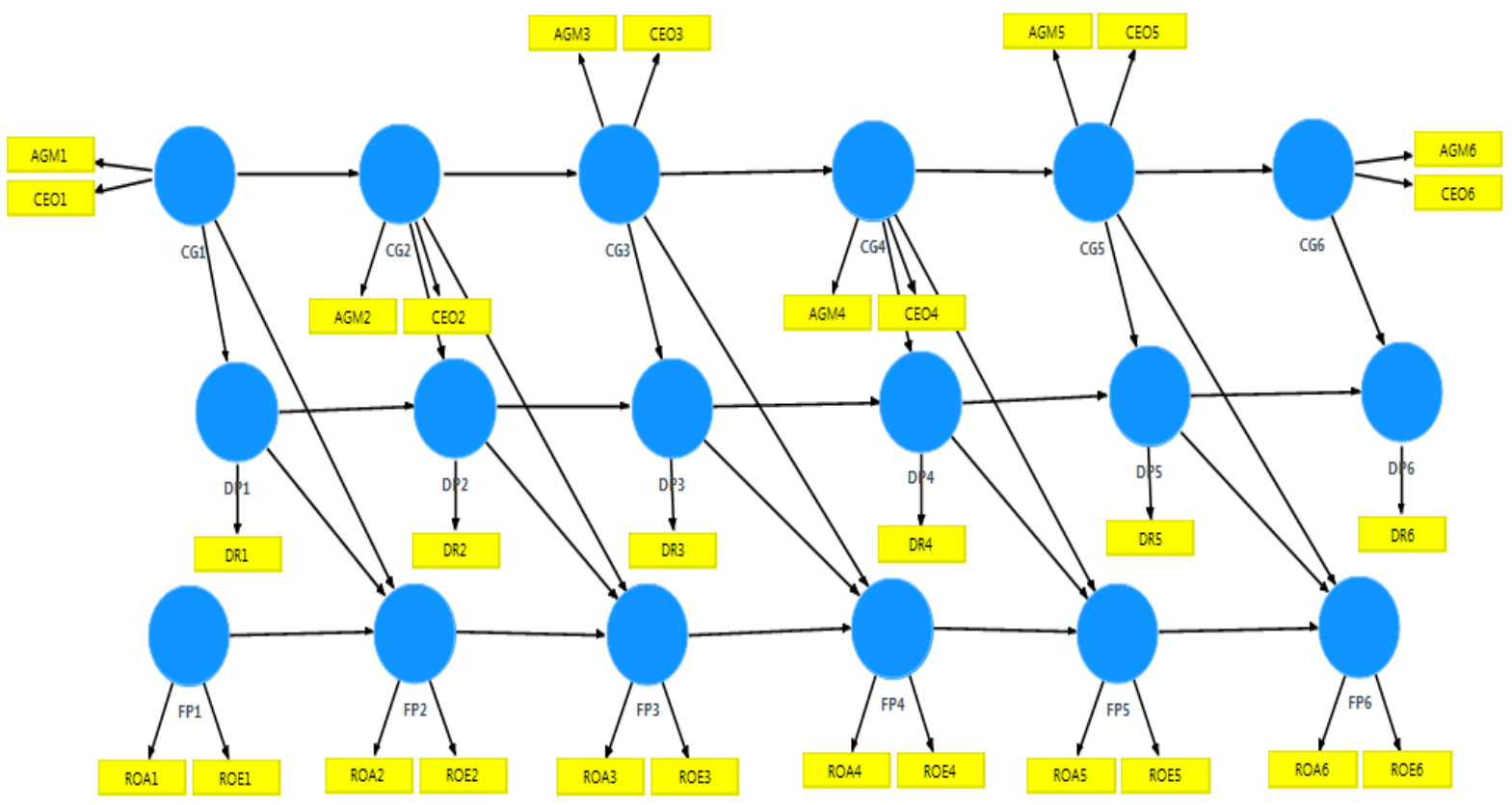




\section{ANNEXURE-B}

\section{Graphs}

Graphical Representation of Model 1A

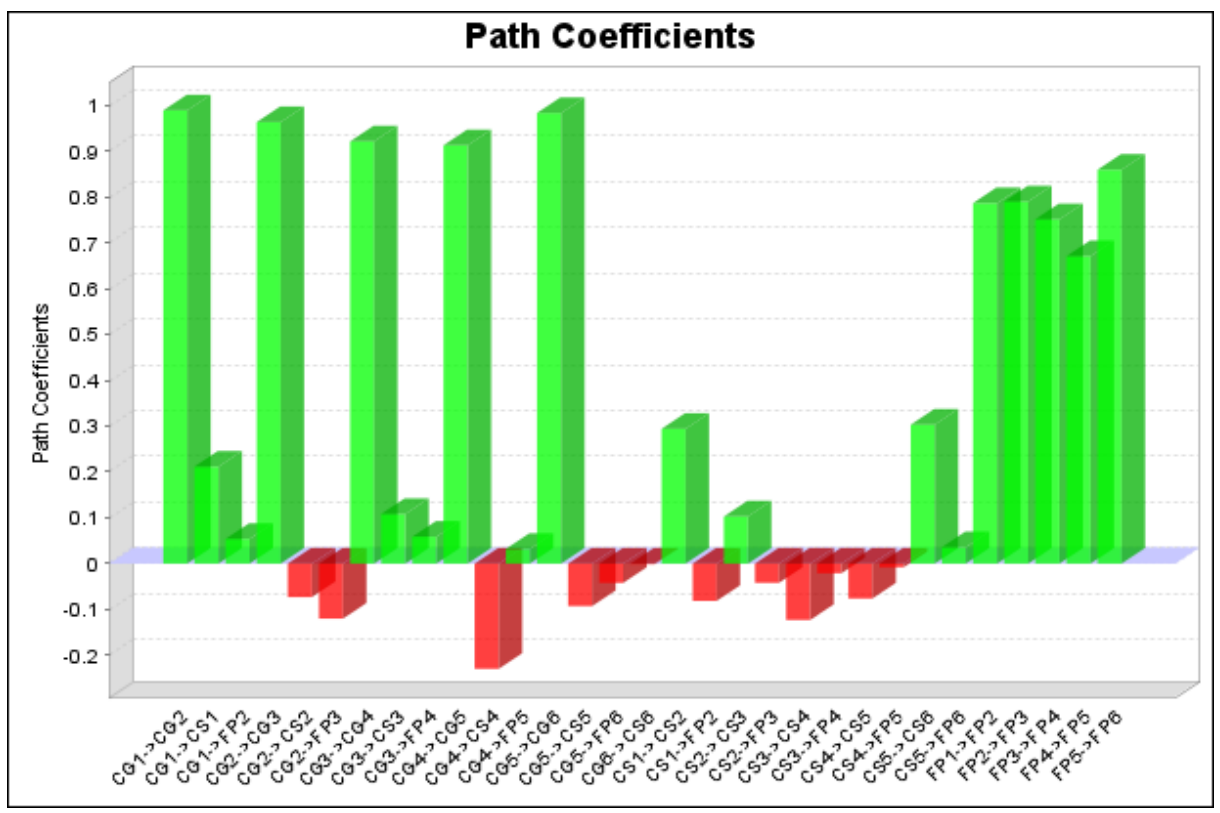

Graphical Representation of Model 2A

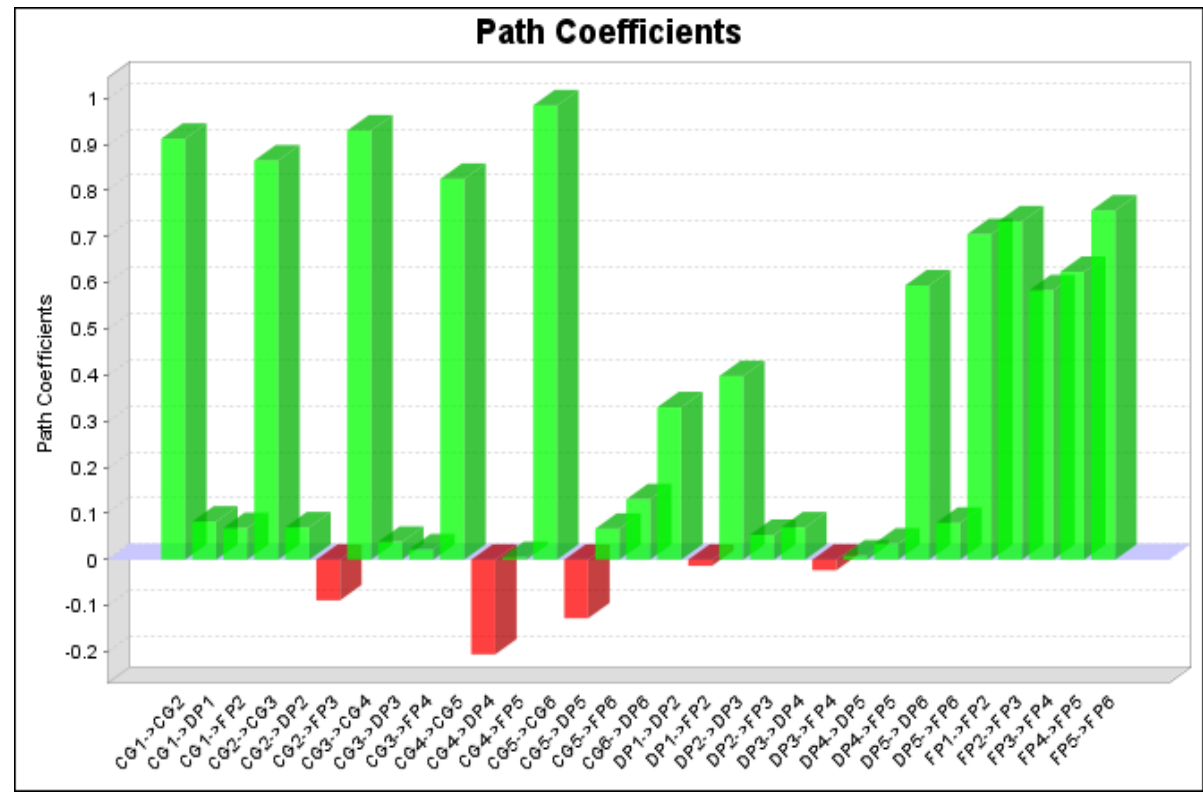


Graphical Representation of Model 1B

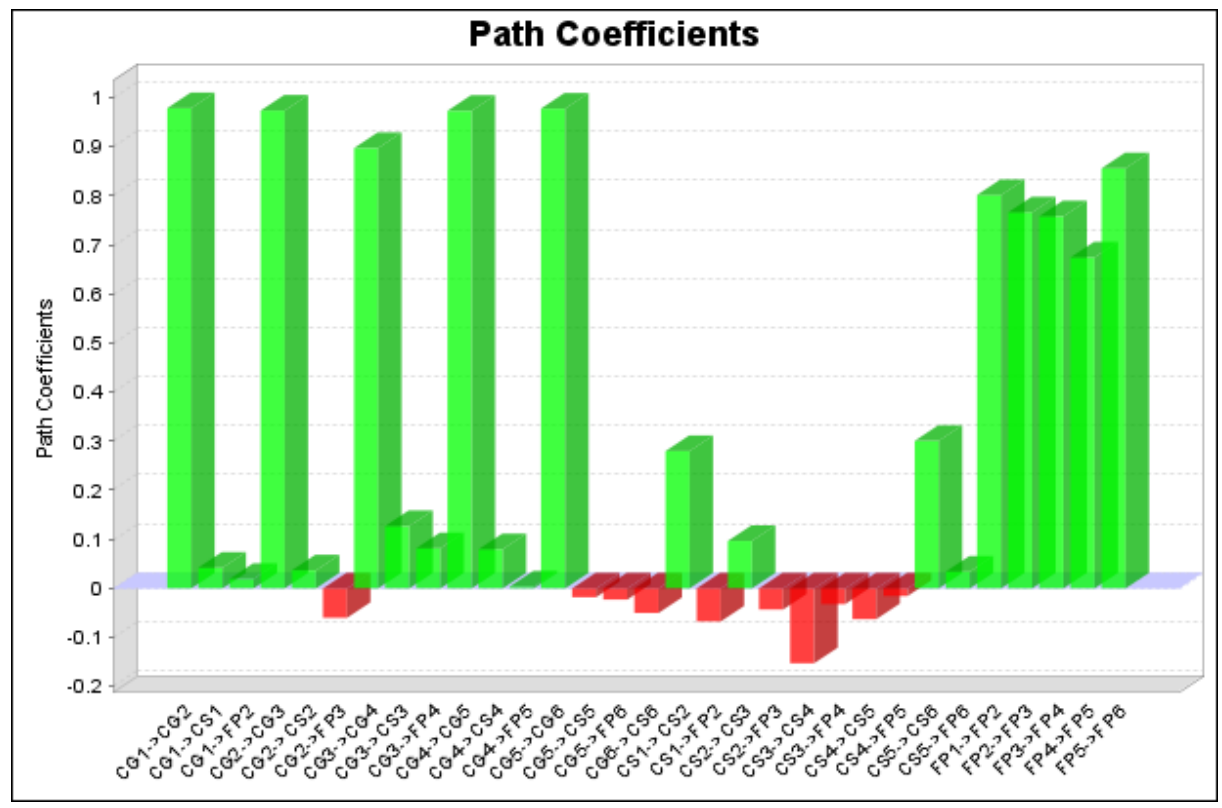

Graphical Representation of Model 2B

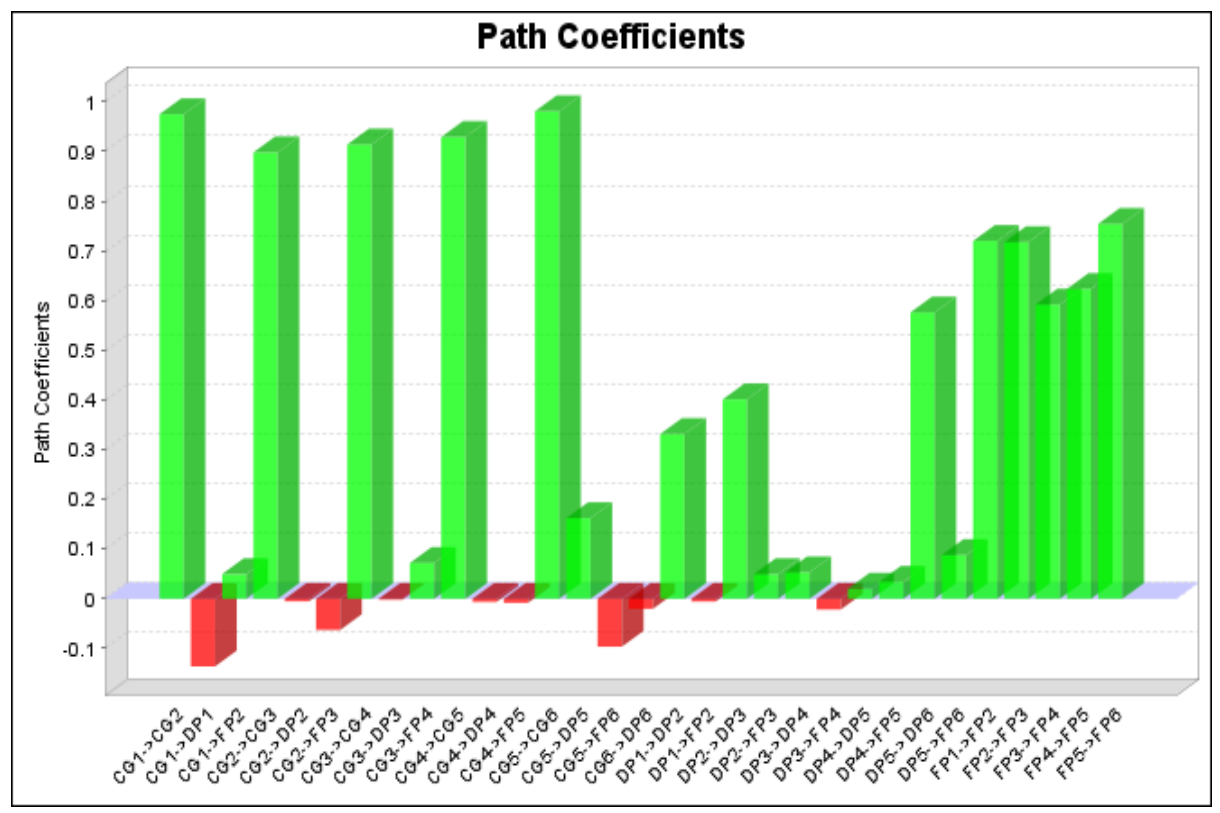

